\title{
Biological, Biochemical and Thermochemical Techniques for Biofuel Production: an Updated Review
}

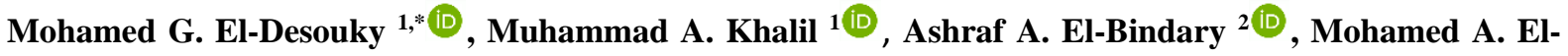 \\ Bindary ${ }^{3}(1)$ \\ 1 Egyptian propylene and polypropylene company, Port Said, Egypt ch.moh.gamal@gmail.com (M.G.E.-D.); \\ magomaa@ hotamil.com (M.A.K.); \\ 2 Chemistry Department, Faculty of Science, Damietta University, Damietta 34517, Egypt \\ 3 Basic Science Department, Higher Institute of Engineering and Technology, Damietta, Egypt \\ * Correspondence: ch.moh.gamal@ gmail.com (M.G.E.-D.);
}

Received: 2.06.2021; Revised: 10.07.2021; Accepted: 15.07.2021; Published: 8.08.2021

\begin{abstract}
Environmental sustainability requirements and rising energy demands, as well as the depletion of conventional energy resources and environmental deterioration as a result of abrupt climate change, have redirected scientists' focus. For sustainable development, look for renewable sources of green and clean energy. Bioenergy is a great alternative because it may be used to meet a variety of energy needs with the right conversion technology. This overview covers all aspects of biofuels (bioethanol, biodiesel, and butanol) and the criteria for their long-term viability. The focus is on the most recent breakthroughs in biofuel production, emphasizing the role of nanotechnology. In addition, a slew of studies is being conducted on developing strategies for process optimization, such as integration methodologies, less energy-intensive distillation processes, and microbe bioengineering talked about. This can assist in making biofuel production in a real-world market more economically and environmentally viable.
\end{abstract}

Keywords: bioethanol; biodiesel; butanol; bioenergy.

(C) 2021 by the authors. This article is an open-access article distributed under the terms and conditions of the Creative Commons Attribution (CC BY) license (https://creativecommons.org/licenses/by/4.0/).

\section{Introduction}

Energy resources will be crucial in the future of the planet. Energy is regarded as a key driver of wealth creation and an important factor in economic growth [1]. There are a variety of modern and renewable energy sources that can be used in place of fossil and traditional fuels. There are three types of energy resources: fossil fuels, renewable resources, and nuclear resources $[2,3]$. In each scenario, the decision of which sorts of energy sources should be used must be based on economic, social, environmental, and safety concerns [4]. Energy's importance in economic development is broadly acknowledged, and historical data confirms that there is a strong link between energy availability and economic activity [5]. Renewable energy resources are also often called alternative sources of energy. Renewable energy resources that use domestic resources can provide energy services with zero or almost zero air pollutants and greenhouse gases emissions. Renewable energy technologies produce marketable energy by converting natural phenomena into useful forms of energy [6,7]. These technologies use the sun's energy and its direct and indirect effects on the earth (solar radiation, wind, falling water, and various plants, i.e., biomass), gravitational forces (tides), and the heat of the earth's core (geothermal) as the resources from which energy is produced. 
Worldwide research and development in the field of renewable energy sources (RES) and systems are carried out during the last two decades [8]. At the end of 2001, the total installed capacity of renewable energy systems was equivalent to $9 \%$ of the total electricity generation. By applying a renewable energy-intensive scenario, the global consumption of renewable sources by 2050 would reach 318 exajoules (1 exajouleZ1018 J) [9-11].

On the other hand, Globally, the proportion of biomass energy will reach $50 \%$ by 2050 in terms of consumption. Biomass, a combination of different organic compounds, is mainly derived from three sources: agricultural residues, forest residues, and energy crops. Generally, biomass refers to rice husk, crop residues, jute sticks, wood, leaves and forest residues, animal waste, municipal waste, etc. [12]. Conversion of biomass into bioenergy for the production of heat and electricity occurs via two widespread technologies: direct combustion and gasification, which play vital roles in the substitution of nonrenewable fossil fuels $[13,14]$. Locally available traditional forms of biomass are used via direct combustion, mostly in rural areas of developing countries. However, increased use of biomass in an efficient way via improved technology can potentially contribute to a clean environment by reducing emissions and representing a promising source of electricity and gas [15-17].

\section{Classification of Biofuel}

Biofuels are classified into different generations based on the feedstocks and conversion methodology, as shown in Figure 1. The 'first-generation' biofuels are derived from edible biomass such as sugar, starch, and vegetable oil [18]. The 'second-generation' biofuels are largely formed of discarded biomass, i.e., the residues of agricultural and forestry feedstocks such as sugarcane leaves, cassava stem, rice straw, and switchgrass [19]. Agricultural feedstock comprises tipi-cellulosic biomass (derived from lignin, cellulose, and hemicelluloses) as the primary components.

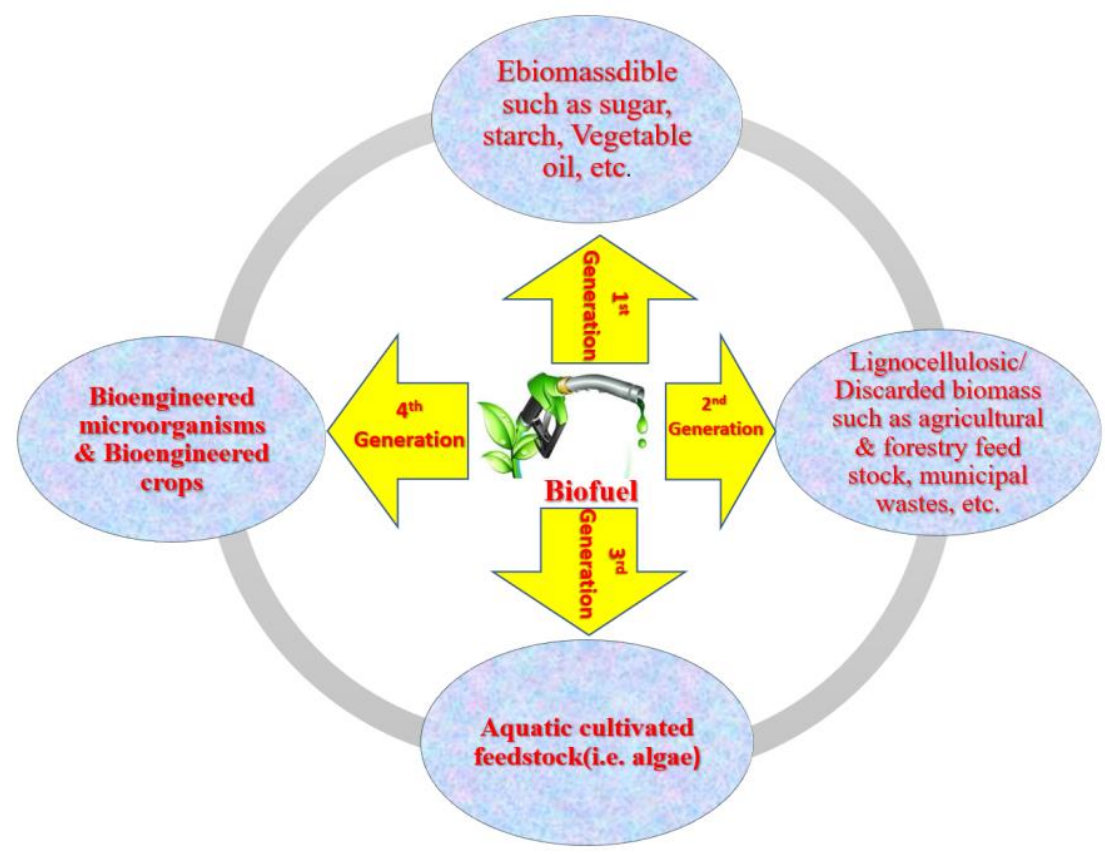

Figure 1. Different generations of biofuels.

The 'third-generation' biofuels are obtained from the algal biomass. Specifically, microalgae organisms are reported to have the supreme ability to create significant Chemicals, and nutritional items are the primary ingredients in biodiesel manufacture. Microalgae offer a number of appealing characteristics, including a high oil content and a low energy requirement. 
The place to expand, the ability to develop in both artificial and natural environments settings with high $\mathrm{CO}_{2}$ fixation efficiency and oxygenic potential photosynthesis, as well as being favorable to the environment[20]. The 'fourth-generation' biofuels are obtained from bioengineered microorganisms like bioengineered algae, yeast, fungi, and cyanobacteria or crops. The development of this generation is still in progress [21,22].

\section{Biofuel Production Methods}

Biochemical methods and biological and thermochemical methods convert primary biomass to biofuel (Figure 2).

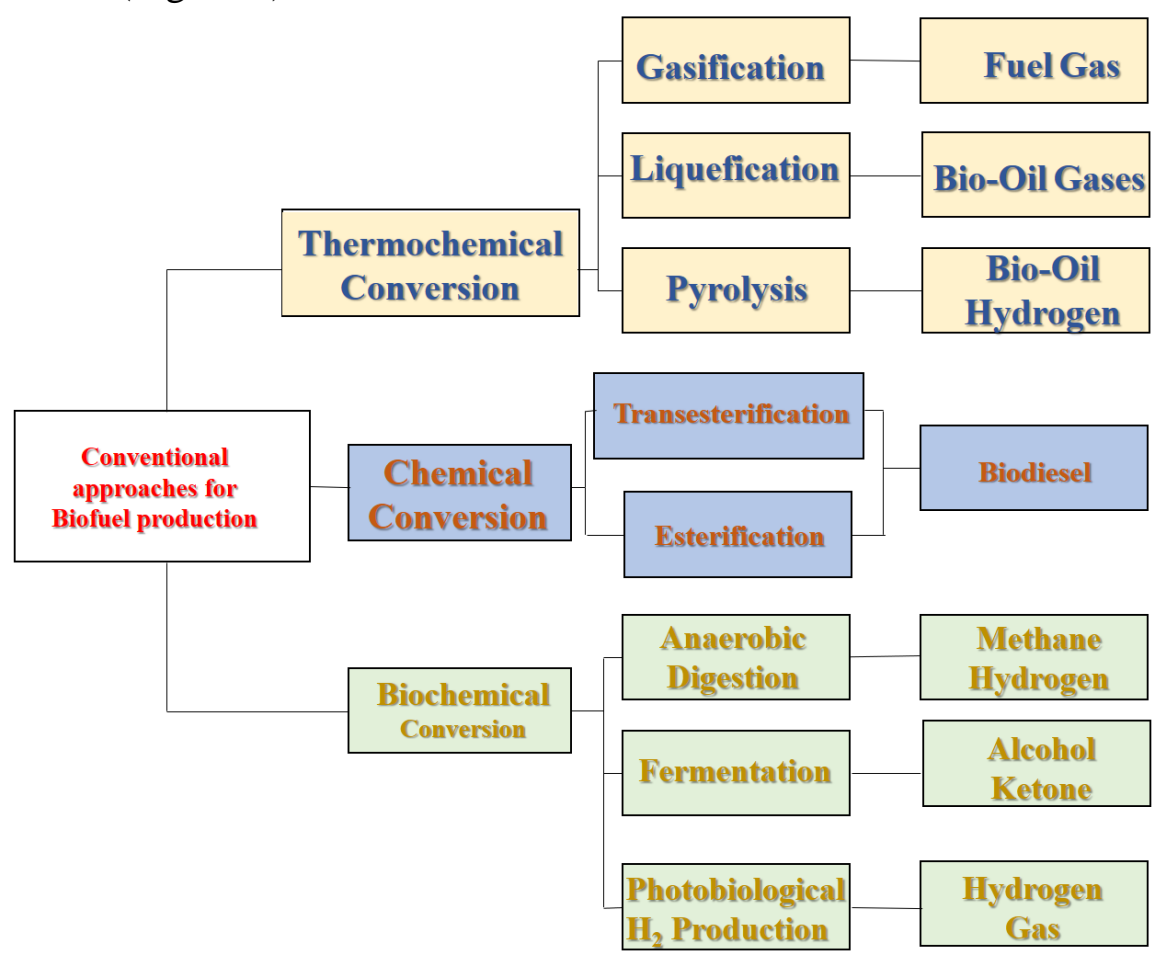

Figure 2. Conventional approaches to the development of biofuels.

\subsection{Thermochemical methods.}

The main thermochemical techniques include pyrolysis, gasification, and liquefaction, briefly discussed here. In pyrolysis, biomass is heated to very high temperatures $\left(300-600{ }^{\circ} \mathrm{C}\right)$ without oxygen to break the polymer structure, subsequently transforming them into liquid (bio-oil), hydrocarbon-rich gas, and solid residues (biochar) [23,24]. In gasification, carbon in the biomass reacts with a sub-stoichiometric amount of oxygen at high temperatures (800-1200 ${ }^{\circ} \mathrm{C}$ ) to get transformed to fuel gas. Different types of reactions (physical and chemical) are carried out in the liquefaction method to transform the biomass into a liquified state at high temperature and pressure [25,26]. The literature has been exhaustive regarding the developments in pyrolysis, gasification, and liquefaction techniques for generating biofuels from various kinds of feedstocks [27].

\subsection{Biological and biochemical methods.}

Biological entities like plants and microorganisms are used directly or indirectly to generate biofuel $[28,29]$. Fermentation of hexoses and pentoses to bioethanol occurs by microbes such as yeast-like Saccharomyces cerevisiae, Pichia stipitis, and bacteria like Zymomonas mobilis. Furthermore, biocatalysts, i.e., enzymes such as lipase and cellulase, 
have a tremendous, tremendous significance for hydrolyzing and breaking polymeric groups in carbohydrate-rich feedstocks [30-32].

\section{Steps of Biomass Conversion}

The major steps involved in biochemical conversion of biomass are enzymatic hydrolysis (saccharification) of carbohydrates for releasing simpler sugars that can subsequently undergo fermentation to give ethanol/butanol, and finally distillation of the fermented broth for the recovery of ethanol $[33,34]$. In the biochemical transformation of lingocellulosic biomass, pretreatment is an essential stage to get rid of the recalcitrance of the lingocellulosic biomass. Lignocellulose is a poly-carbohydrate complex constituting of lignin, cellulose, besides hemicellulose. The pretreatment helps to make the biomass more vulnerable toward hydrolysis by breaking tipi-cellulosic matrix, decreasing the cellulose crystallinity, and increasing the portion of amorphous cellulose by enhancing the surface area reasons for recalcitrance. Delignifcation or altering lignin is the main purpose of pretreatment $[35,36]$. The algal biomass may not have delignifcation as a primary lookout. Nonetheless, the microalgal cell wall constitutes cellulose and pectin, giving an inflexible structure, reducing biomass accessibility to the hydrolytic enzymes. The disintegration of cell wall structure besides modification of the structure of intracellular carbohydrates such as starch and cellulose are the main intents of pretreatment in this situation [37,38]. The pretreatment technique may be physical, chemical, physicochemical, or biological. The physical technique includes pyrolysis, size reduction, and microwave heating, while acid/alkali treatments are part of chemical pretreatment techniques [12]. The physicochemical techniques comprise of using wet oxidation, ammonia fiber, steam explosion, whereas biological technique involves microbial treatment [39]. In addition, improving the bioactivity of microbes that perform fermentation to give ethanol and a decrease in the formation of inhibitory compounds such as acetic acid, ketone, and phenolics is essential to achieve high ethanol concentrations. Furthermore, biodiesel is produced via transesterification of triglycerides (waste oil or algal biomass) with alcohol using a catalyst. Parameters such as pressure, temperature, molar ratios of alcohol-tooil, time, catalyst concentration, and type of feedstock have an effect on the trans-esterification process $[40,41]$.

\section{Conversion Processes}

\subsection{Biochemical conversion processes.}

\subsubsection{Pretreatment.}

The goal of the pretreatment stage is to raise the lignocellulosic material's surface area, break the lignocellulose structure so that the cellulose component is accessible to hydrolyzing agents, and diminish the crystallinity of the cellulose to enable hydrolysis even further. This stage may also include the solubilization of the lignin or hemicellulose component, depending on the pretreatment process used. A variety of pretreatment alternatives are currently available to fractionate, solubilize, hydrolyze, and separate cellulose, hemicellulose, and lignin components [42]. Physical, physicochemical, chemical, and biological pretreatments are among them. As a result, pretreatment is a key cost component of the entire lignocellulosic bioethanol process [43]. 


\subsubsection{Feedstock size reduction.}

Cleaning comes first in the process of making ethanol from biomass, followed by mechanical comminution, which includes chipping, grinding, and milling to break down lignocellulosic materials to 0.2 to $2 \mathrm{~mm}$ reduce the crystallinity of the materials. Size reduction is necessary to provide a pumpable slurry and increase the biomass surface area to minimize mass transfer effects during the downstream processes. Techniques for size reduction include a hammer, disk, and knife milling and are well established [43].

\subsubsection{Hydrolysis.}

The complicated chains of sugars that make up hemicellulose are broken during the hydrolysis event, releasing simple sugars. The soluble five-carbon sugars xylose and arabinose, as well as soluble six-carbon sugars mannose and galactose, are formed from the complex hemicellulose carbohydrates. Weak acids, furan derivates, and phenolics are formed from the remaining hemicelluloses. These chemicals, on the other hand, have the ability to impede fermentation. The glucose yields of cellulose hydrolysis are frequently greater than $90 \%$ due to the action of dilute acids, concentrated acids, and/or enzymes (Cellulase), whereas hydrolysis without prior pretreatment yields typically less than $20 \%$ [44]. The cellulose hydrolysis reactions can be simply represented as:

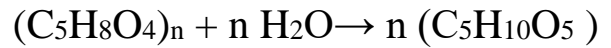

$$
\begin{aligned}
& \left(\mathrm{C}_{6} \mathrm{H}_{10} \mathrm{O}_{5}\right)_{\mathrm{n}}+\mathrm{n} \mathrm{H}_{2} \mathrm{O} \rightarrow \mathrm{n}\left(\mathrm{C}_{6} \mathrm{H}_{12} \mathrm{O}_{6}\right)
\end{aligned}
$$

The pretreated feedstock can be hydrolyzed by two methods (Acid hydrolysis and Enzyme hydrolysis).

\subsubsection{Acid hydrolysis.}

Various acid hydrolysis processes have been developed in the past. The many acid hydrolysis technologies can be classified into two groups: i) low-temperature hydrolysis with concentrated acid; ii) At high temperatures, dilute acid is hydrolyzed. Acid hydrolysis has a long industrial history, but it comes with significant running costs and many environmental and corrosion issues [45].

- Hydrolysis of a dilute acid - The dilute acid process is carried out at high temperatures and pressures, with a reaction time of minutes or less, allowing for continuous processing.

- Hydrolysis of concentrated acid - With a substantially longer reaction period, the concentrated acid procedure employs very mild conditions.

\subsubsection{Enzyme hydrolysis.}

Enzymatic hydrolysis is another common form of hydrolysis. Plant enzymes are naturally occurring proteins that catalyze chemical processes. Enzymatic hydrolysis has yet to be commercialized, yet it is widely acknowledged as the most promising hydrolysis method. It is possible to reduce the cost of ethanol production by lowering the cost of either the raw ingredients or the cellulase enzyme [46]. Reducing the cost of cellulase enzyme production is a key issue in the enzymatic hydrolysis of lignocellulosic materials. Enzymatic hydrolysis of cellulose is usually carried out by cellulase enzymes. During hydrolysis, cellulose is degraded into the reducing sugars that yeasts or bacteria can ferment to ethanol $[47,48]$. 


\subsection{Anaerobic digestion $(A D)$.}

Wet organic waste is frequently recycled and treated using anaerobic digestion. It's a tried-and-true technology [49,50]. It comes in fermentation that transforms organic substances into biogas, mostly methane (approximately 60\%) and carbon dioxide (approximately 40\%) and landfill gas. Anaerobic digestion is a biologically natural technique of conversion in which bacteria break down biodegradable material in the absence of oxygen, resulting in biogas, a mixture of predominantly methane and carbon dioxide with tiny amounts of other gases such as hydrogen sulfide. Through anaerobic fermentation in the absence of oxygen, biomass is converted into animal dung, human waste, and other organic waste with a high moisture content into biogas (gobar gas). Fermentation is carried out on two levels by bacteria belonging to two separate metabolic families. The organic substance is first hydrolyzed to produce fatty acids, alcohols, and sugars.

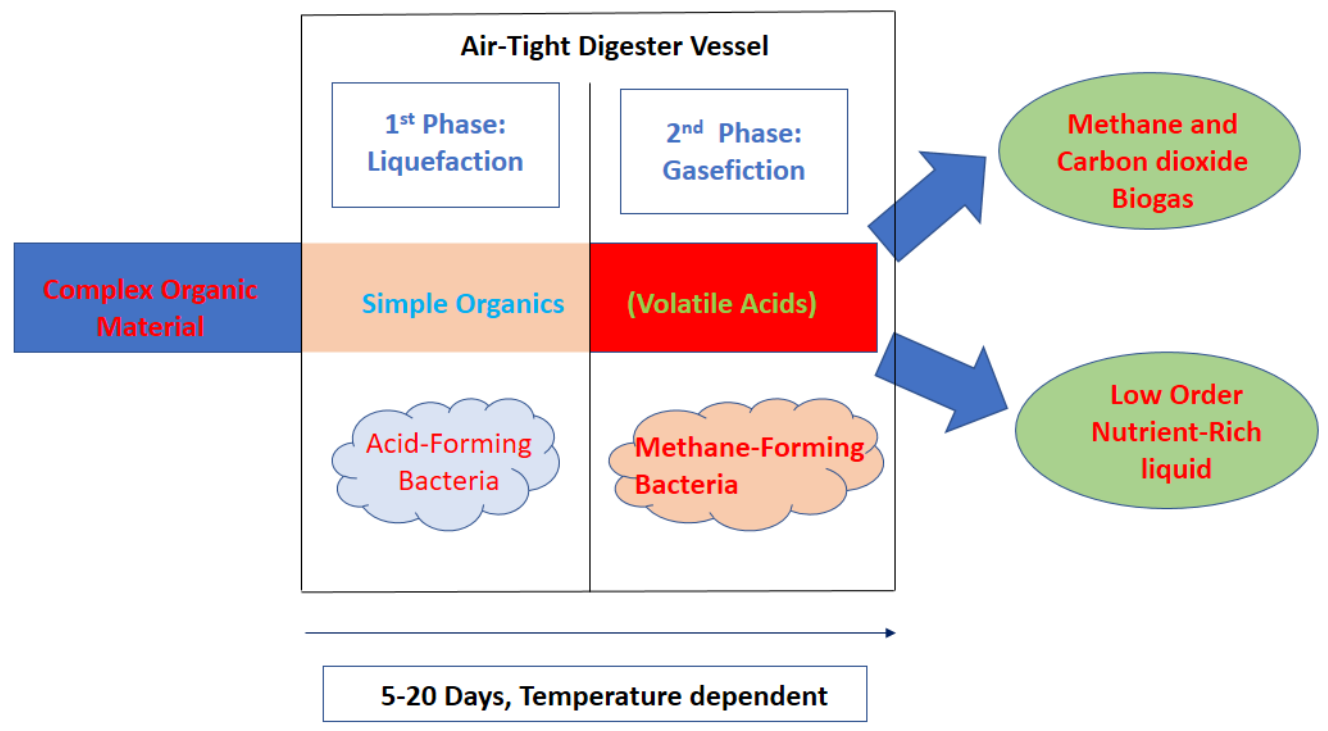

Figure 2. Working of anaerobic processes.

Table 1. Characteristic of anaerobic digestion.

\begin{tabular}{l|l}
\multicolumn{1}{c|}{ Characteristic } & Anaerobic \\
\hline Reaction & $\mathrm{C}_{6} \mathrm{H}_{12} \mathrm{O}_{6} \longrightarrow \mathrm{CO}_{2}+3 \mathrm{CH}_{4}$ \\
\hline Energy Release & $\Delta \mathrm{G}^{\circ}=-393 \mathrm{KJ} / \mathrm{mol}$ glucose \\
\hline Carbon Balance & $95 \% \longrightarrow \mathrm{CO}_{2}+\mathrm{CH}_{4}$ \\
\hline & $(\mathrm{Biogas}) 5 \% \longrightarrow$ Biomass \\
Energy Balance & $90 \%$ retained in $\mathrm{CH}_{4} 5 \% \rightarrow$ Biomass \\
\hline Biomass Production & $5 \% \longrightarrow$ Heat production
\end{tabular}

Biogas and digestate are the two products produced by an anaerobic digestion plant; both can be further processed or used to make secondary goods [51]. Biogas can be used to generate electricity and heat, as well as a natural gas replacement and transportation fuel. Biogas can be improved and used in gas distribution systems. Digestate can be treated further to create liquor and fibrous material. (Tables 1,2, and 3). The fiber, which can be composted, 
is a bulky substance with low nutrient levels that can be used as a soil conditioner or low-level fertilizer [52-54]. The liquor retains a large proportion of the nutrients and can be used as a liquid fertilizer (Figure 2).

Table 2. Advantages and disadvantages of anaerobic digestion.

Advantage

-Reduces odor below unprocessed waste odor levels

- Reduces harmful gas emissions

- Reduces oxygen demand in wastewater

- Can produce valuable by-products (compost and fertilizer)
Disadvantage

- Installation cost is high

- Anaerobic digesters are economically beneficial only for larger farms

- Long time required for system operation and maintenance - The larger the farm, the greater the land use might be for the manure tank, as well as the digester

Table 3. Summary of some works for anaerobic digestion.

\begin{tabular}{c|c|c|c} 
Microalgae species & $\begin{array}{c}\text { Methane yield [mL g } \\
1 \mathrm{VS}]\end{array}$ & Loading rate & Ref. \\
\hline Blue-green algae & 366 & $281.96 \mathrm{mg} \mathrm{VS} \mathrm{L} \mathrm{d}^{-1}$ & {$[55]$} \\
\hline Chlorella vulgaris & 403 & $2 \mathrm{~g} \mathrm{VS} \mathrm{L}^{-1} \mathrm{~d}^{-1}$ & {$[56]$} \\
\hline Chlorella vulgaris & 286 & $2 \mathrm{~g} \mathrm{VS} \mathrm{L}^{-1} \mathrm{~d}^{-1}$ & {$[57]$} \\
\hline Dunaliella salina & 505 & $3 \mathrm{~g} \mathrm{TS} \mathrm{L}^{-1} \mathrm{~d}^{-1}$ & {$[57]$} \\
\hline Macrocystis pyrifera & 545 & $2 \mathrm{~g} \mathrm{TS} \mathrm{L} \mathrm{L}^{-1} \mathrm{~d}^{-1}$ & {$[57]$} \\
\hline Scenedesmus obliquus & 287 & $910 \mathrm{mg} \mathrm{VS} \mathrm{L}^{-1} \mathrm{~d}^{-1}$ & {$[58]$} \\
\hline Spirulina maxima & 320 & {$[59]$}
\end{tabular}

TS, total solids; VS, volatile solids.

\subsubsection{Digester designs.}

Four main anaerobic digesters are generally used: covered lagoon digesters (CLD); completely mixed digesters (with the same properties as a continuous stirred-tank reactor (CSTR) system); fixed-film digesters; plug-flow digesters.

In a well-mixed digester, documented the production of biogas using swine manure waste. Biogas at $1.5 \mathrm{~m}^{3} \mathrm{~m}^{-3} \mathrm{~d}^{-1}$ was provided with 83 percent VS removal in this sample. A higher OLR offers greater production of biogas. In a cow farm where $3.25 \mathrm{~m}^{3} \mathrm{~m}^{-3} \mathrm{~d}^{-1}$ of biogas was generated ( 70 percent of it is methane) with the removal of about 67 percent of VS and COD, another investigation was carried out. The residence time is reduced to the range of 1-6 days by fixed-film systems. For these systems, the OLR values are in the 5-10 $\mathrm{kg} \mathrm{COD} \mathrm{m}^{-3} \mathrm{~d}^{-1}$ range. In Florida, a fixed-film system treated dairy manure waste with 2210 and $3530 \mathrm{~kg} \mathrm{~m}-3$ VS and COD feed, respectively, and methane production reached $0.36 \mathrm{~m}^{3} \mathrm{~m}^{-3} \mathrm{~d}^{-1}$. Another fixed film digester for diary manure (in New York) uses $6.1 \mathrm{~m}^{3} \mathrm{~m}^{-3} \mathrm{~d}^{-1}$ segregated manure. It was found that the development rate of biogas was $1.73 \mathrm{~m}^{3} \mathrm{~m}^{-3} \mathrm{~d}^{-1}$. The anaerobic digester plug-flow form is more environmentally friendly than the others [60].

Table 4. CLD productivity.

\begin{tabular}{|c|c|c|c|c|c|}
\hline CLD Type & Volume & Loading & Biogas & Productivity & Ref. \\
\hline Swine and dairy operations & & $0.04-0.36 \mathrm{~kg} \mathrm{VS} \mathrm{m}^{-3} \mathrm{~d}^{-1}$ & Methane & $0.03-0.15 \mathrm{~m}^{3} \mathrm{~m}^{-3} \mathrm{~d}^{-1}$ & [61] \\
\hline \multirow{2}{*}{$\begin{array}{c}\text { 4000-sow swine farm in the } \\
\text { USA }\end{array}$} & \multirow{2}{*}{$24480 \mathrm{~m}^{3}$} & \multirow{2}{*}{$0.07 \mathrm{~kg} \mathrm{VS} \mathrm{m}^{-3} \mathrm{~d}^{-1}$} & \multirow{2}{*}{ Methane } & $0.0247 \mathrm{~m}^{3} \mathrm{~m}^{-3} \mathrm{~d}^{-1}$ (Summer) & [62] \\
\hline & & & & $0.0124 \mathrm{~m}^{3} \mathrm{~m}^{-3} \mathrm{~d}^{-1}$ (Winter) & [63] \\
\hline CLD-treated dairy manure & $2060 \mathrm{~m}^{3}$ & $0.12 \mathrm{~kg} \mathrm{VS} \mathrm{m}^{-3} \mathrm{~d}^{-1}$ & Methane & $0.042 \mathrm{~m}^{3} \mathrm{~m}^{-3} \mathrm{~d}^{-1}$ & \\
\hline
\end{tabular}

For this type, the average retention period ranges from 20 to 30 days. An example of regular operations has been studied with a retention period of 21 to 40 days. The output rate of 
methane reached $0.503 \mathrm{~m}^{3} \mathrm{~m}^{-3} \mathrm{~d}^{-1}$, and 25 percent TS and 33 percent VS were eliminated. Figure 3 compares the production of biogas among the four forms of anaerobic digesters. It can be assumed that the fully mixed and fixed-film digesters have a greater biogas output rate than the other digesters Table 4.

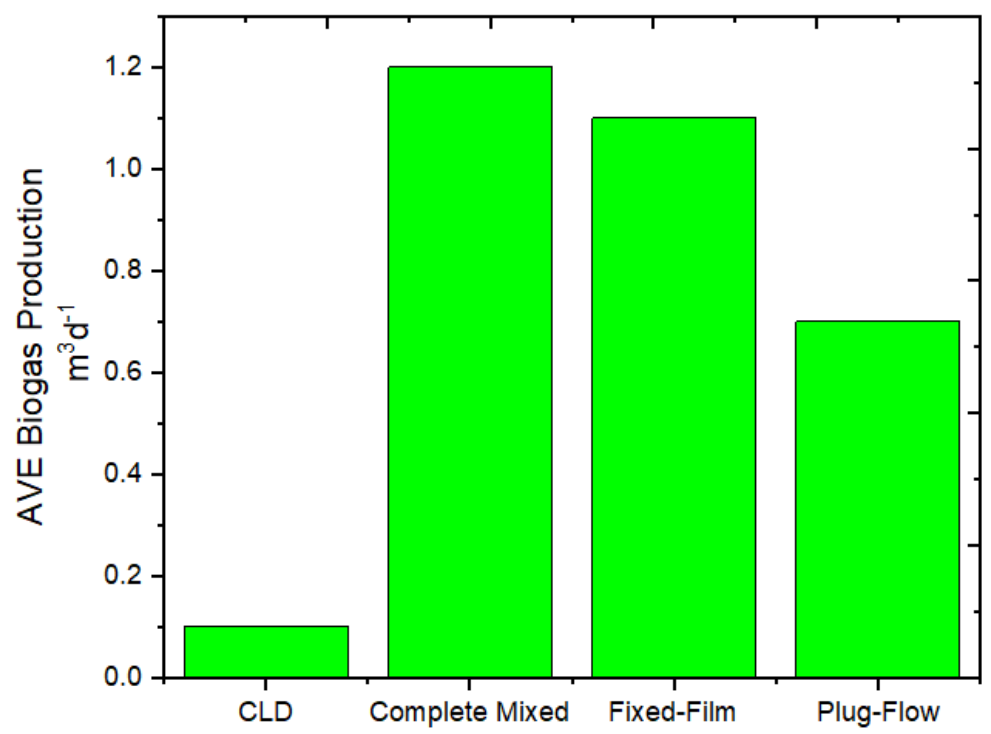

Figure 3. Comparison between different digesters.

\subsection{Fermentation.}

Another biological mechanism functions in the absence of oxygen is the help of microorganisms to turn sugar into essentially alcohol, acid, or a mixture of gases $\left(\mathrm{CO}\right.$ and $\left.\mathrm{H}_{2} \mathrm{~S}\right)$; the biomass is reduced to smaller particles, and starch is then converted to starch transformed with the help of enzymes into sugar and then into alcohol. A number of substrates, It is converted into starch biomass, lignocellulosic biomass, and algal biomass, such as Sugar fermentable $[64,65]$. However, it is difficult to ferment agricultural waste because it has complex long-chain polymeric molecules and requires acid or enzymatic hydrolysis before fermenting the sugar into alcohol. Fermentation is a long, time-consuming operation, with the risk of other foreign microorganisms being infected. It is an optimistic strategy, but high costs hinder its transition from laboratory to commercial. Biomass residues for renewable energy and bioproducts in general refining butanol and ethanol are processed by fermentation. Biobutanol is a microorganism formed by Clostridium spp. Using sugar derived from various biomass sources [66]. The method is referred to as the fermentation of acetone, butanol, and ethanol (ABE), comprising two phases of acetogenesis and solventogenesis. In a report, the production of $\mathrm{ABE}$ from corn processing waste with Clostridium beijerinckii SE-2was $19.22 \mathrm{~g} / \mathrm{L}$, which contained a butanol yield of $11.65 \mathrm{~g} / \mathrm{L}$. There is a higher heating value, lower volatility, lower ignition and viscosity of biobutanol than bioethanol. In addition to these benefits, bioethanol is a well-established technique due to lower cost and high output yield than biobutanol compared to biobutanol. Yeasts, such as Saccharomyces cerevisiae, Candida albicans, Pichia pastoris, and Kluyveromyces, are mainly used for bioethanol production due to their high productivity of $>1 \mathrm{~g} / \mathrm{L} / \mathrm{h}$ and the need for easy, inexpensive growth media. Basically, for bioethanol processing, separate hydrolysis and fermentation, simultaneous saccharification and fermentation, and simultaneous saccharification and co-fermentation, three fermentation techniques are used. The optimum fermentation temperature, $\mathrm{pH}$, and agitation speed range for $\mathrm{S}$ is $20^{\circ} \mathrm{C}-35^{\circ} \mathrm{C}, 4-5$, and $150-200 \mathrm{rpm}$, respectively [67,68]. Cerevisiae. All right. From the 
fermentation of industrial algae waste using S, a yield of $11.6 \mathrm{~g} \mathrm{EtOH/algae} \mathrm{was} \mathrm{achieved.}$ Cerevisiae is a microorganism for fermentation. Apart from yeast, some optional genetically modified anaerobic bacteria, such as Zymomonas mobilis, are also used for bioethanol production (Figure 5).

Agricultural Waste + microorganisms $\longrightarrow$ Biogas + digestate

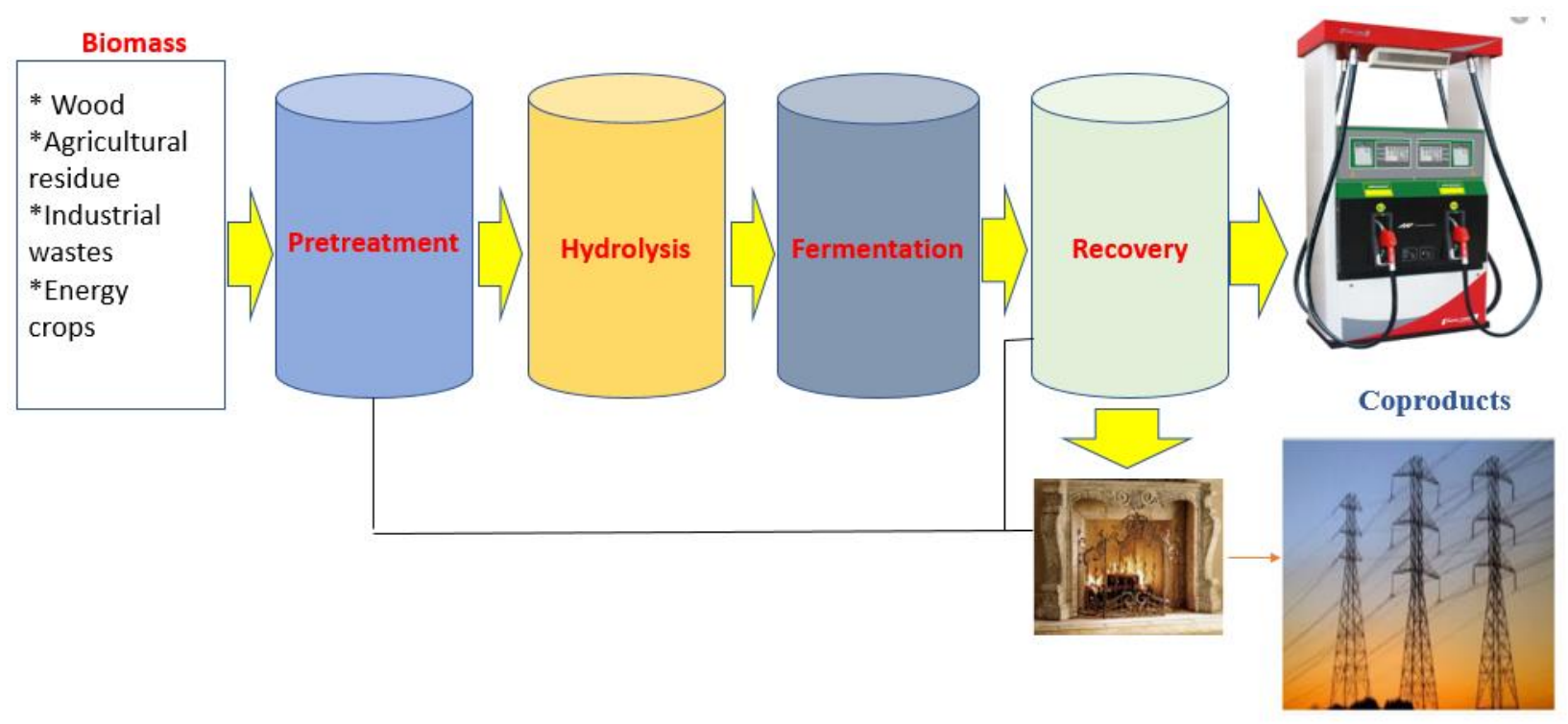

Figure 5. Biochemical conversion of biomass to the product. The basic unit processes steps for conversion of biomass material to products such as biofuel and electricity.

\subsection{Distillation.}

The process of isolating ethanol from the fermentation solution once it has begun to form during fermentation is known as the separation of ethanol from the fermentation solution. The fermentation solution is likely to contain water, ethanol, and any residual biomass. One of the first separation methods used by alchemists and pharmacists was the distillation. In general, distillation, along with chromatography and filtering, is still considered a key method of separating and purifying substances [69]. A second distillation can be employed to concentrate the separated ethanol, which is usually not suitable for use as a fuel (at least 95 percent ethanol by volume). A method for producing and recovering light alcohols, such as ethanol, ethanol blends, and ABE mixtures (alcohol mixtures containing acetone, ethanol and butanol), fermentation, first membrane separation, dephlegmation, and dehydration by second membrane separation are some of the steps used [57].

\subsection{Harvesting technique.}

The biomass can be processed into biofuel after the cultivation process, such as biodiesel or bioalcohol, depending on the amount of lipids or sugars accumulated. To replace mineral oil, biodiesel can be used. It is reusable, and when burned, less toxic compounds are released. Some algal species can produce up to $60 \%$ of their oil weight to turn it into biodiesel and are therefore considered the most promising source of biodiesel production. The steps involved in biodiesel development are harvesting, dehydration, oil extraction, and converting biodiesel oil [70]. 
Harvesting is known as algae extraction from its field of cultivation. After harvesting the algae, the drying process and other processes for obtaining the required products are obtained. In terms of mass production, processing and harvesting are essential, but these processes are costly. The procedure to be used depends mainly on the finished product and strains of culture. Some characteristics of microalgae have an effect on the size and density of the harvesting process. The size and density of microalgae make it difficult for them to harvest for biomass production because microalgae are very small and have a low cell density ranging from 0.3 to $0.5 \mathrm{~g} / \mathrm{L}$, with only a few cases exceeding $5 \mathrm{~g}$ and around 1 to $20 \mu \mathrm{m}$ in size. The industrial-scale sets ideal criteria to contain at least $300-400 \mathrm{~g} / \mathrm{L}$ of cell sludge. That means it is important to concentrate suspended microalgae at least 100 times, which is an energy-intensive operation. Algae processing is based on the idea of solid-liquid processes being isolated [71]. Thickening the suspension of algae before a dense algal slurry or cake forms is one of the crucial harvesting stages. However, the water content should be decreased as much as possible to allow for harvesting and processing [72]. Two phases of the process of algae harvesting are Figure 6 and Table 5.

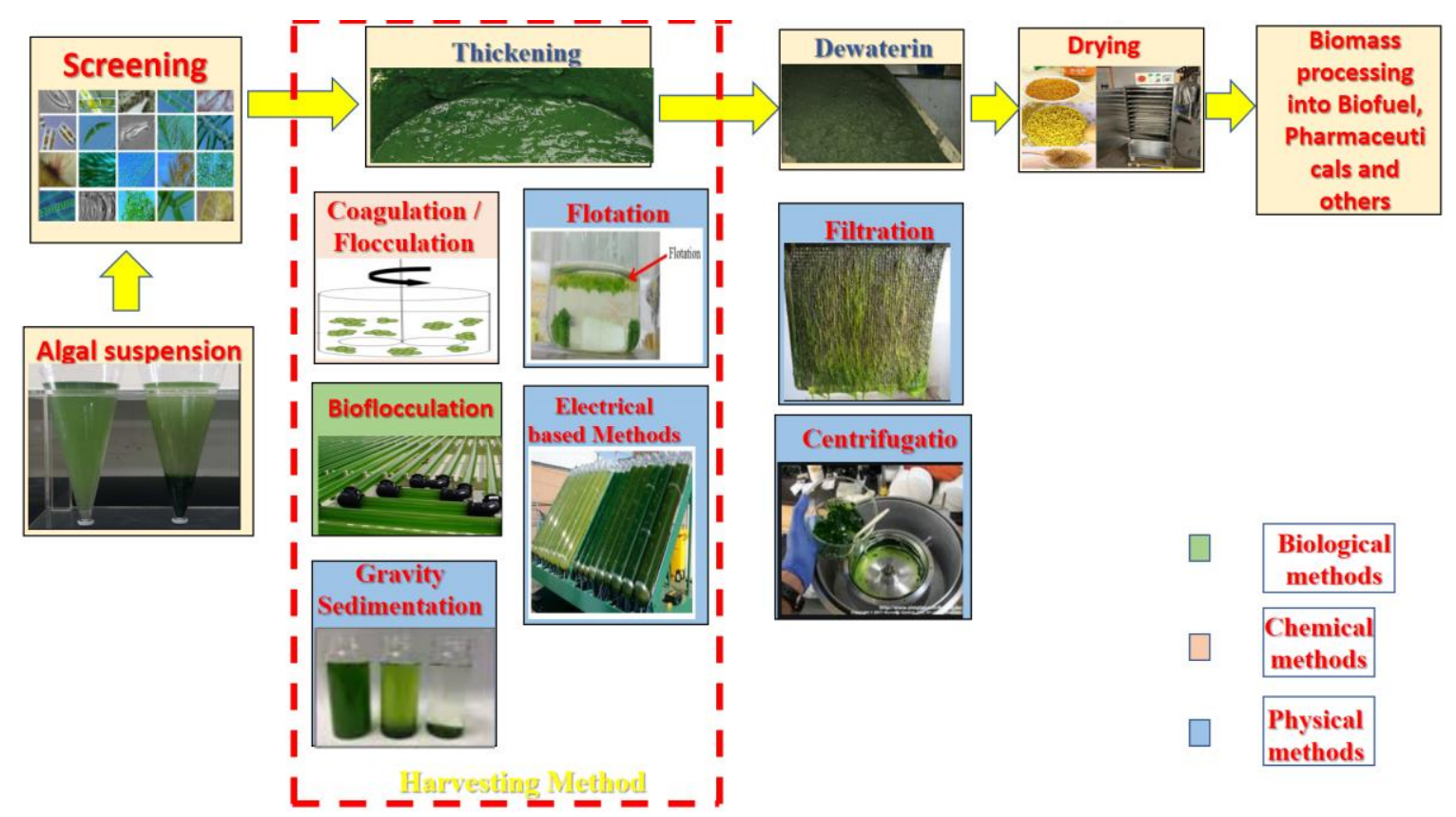

Figure 6. Drying and harvesting techniques.

Table 5 summarizes the advantages and disadvantages of each of the harvesting methods discussed.

\begin{tabular}{l|l|l} 
Harvesting methods & Advantages & Disadvantages \\
\hline $\begin{array}{l}\text { Chemical coagulation- } \\
\text { flocculation }\end{array}$ & $\begin{array}{l}\text { - Simple and fast method. } \\
\text { - No energy requirements. }\end{array}$ & $\begin{array}{l}\text {-Chemical flocculants may be expensive and toxic to } \\
\text { microalgal biomass. } \\
\text {-Recycling of culture medium is limited. }\end{array}$ \\
\hline Auto and bioflocculation & $\begin{array}{l}\text { - Inexpensive method. } \\
\text { - Allows culture medium } \\
\text { recycling. } \\
\text { - Non-toxic to microalgal biomass. }\end{array}$ & $\begin{array}{l}\text {-Changes in cellular composition. } \\
\text {-Possibility of microbiological contamination. }\end{array}$ \\
\hline Gravity sedimentation & - Simple and inexpensive method. & $\begin{array}{l}\text {-Time-consuming. } \\
\text { - Possibility of biomass deterioration. } \\
\text { - Low concentration of the algal cake. }\end{array}$
\end{tabular}




\begin{tabular}{l|l|l}
\hline Harvesting methods & Advantages & Disadvantages \\
\hline Flotation & $\begin{array}{l}\text {-Feasible for large scale } \\
\text { applications } \\
\text {-Low-cost method. } \\
\text {-Low space requirements. } \\
\text {-Short operation times. }\end{array}$ & $\begin{array}{l}\text {-Generally, it requires the use of chemical flocculants. } \\
\text {-Unfeasible for marine microalgae harvesting. }\end{array}$ \\
\hline Electrical based processes & $\begin{array}{l}\text {-Applicable to a wide variety of } \\
\text { microalgal species. } \\
\text {-Do not require the addition of } \\
\text { chemical flocculants. }\end{array}$ & $\begin{array}{l}\text {-Poorly disseminated. } \\
\text {-High energetic and equipment costs. }\end{array}$ \\
\hline Filtration & $\begin{array}{l}\text {-High recovery efficiencies. } \\
\text {-Allows the separation of hearing- } \\
\text { sensitive species. }\end{array}$ & $\begin{array}{l}\text {-The possibility of fouling/clogging increases } \\
\text { operational costs. } \\
\text {-Membranes should be regularly cleaned. } \\
\text {-Membrane replacement and pumping represent the } \\
\text { major associated costs. }\end{array}$ \\
\hline Centrifugation & $\begin{array}{l}\text {-Fast method. } \\
\text {-High recovery efficiencies. } \\
\text {-Suitable for almost all microalgal } \\
\text { species. }\end{array}$ & $\begin{array}{l}\text {-Expensive method. } \\
\text {-High energy requirements. } \\
\text {-Suitable only for the recovery of high-value } \\
\text { products. } \\
\text {-Possibility of cell damage due to high shear forces. }\end{array}$
\end{tabular}

Bulk processing: the elimination of algae from bulk suspension. In this method, through the use of flotation, gravity sedimentation, or flocculation, total solid matter can be about 2-7 percent.

Thickening: using such methods to concentrate the slurry, such as ultrasonic aggregation, filtration, and centrifugation. This is, therefore, typically a more energy-intensive phase than the bulk process.

Essentially, the alternative for algae harvesting technology must be energy-efficient and relatively cheap for viable production [73]. The methods of extraction used are important for the final slurry concentration, which affects the necessary energy input. Thickening, dewatering, and/or drying are used in the harvesting method (Figure 7).

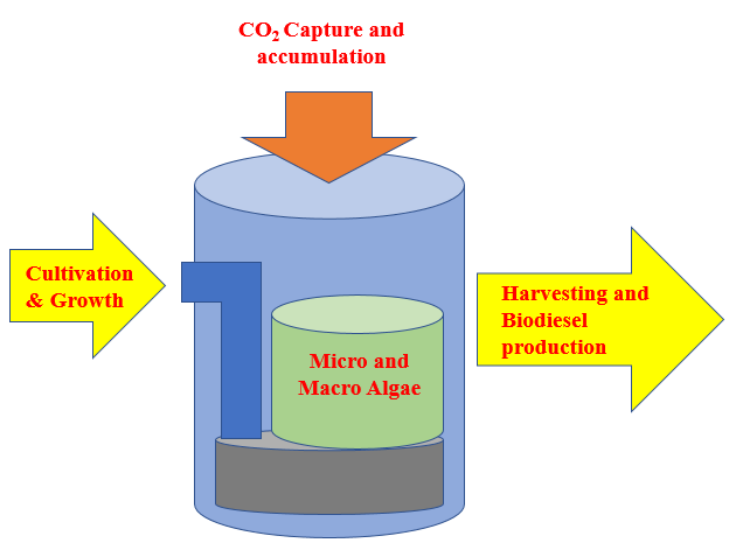

Figure 7. Harvesting and biodiesel production.

\section{Production of Biofuel}

\subsection{Production of bioethanol.}

Fermenting biomass, which includes carbohydrates, cellulose, and starch, produces bioethanol. The sequential steps involved in the overall development process for bioethanol are illustrated in Figure 8. In the traditional fermentation process, in the presence of enzymes or acids, finely ground biomass is first converted into sugars; then it is further processed by yeasts that convert the sugars into ethanol. For the separation of the ethanol, a distillation column is used at the top. The high ethanol concentration stream is liquefied, which can be used in cars 
as an additional fuel. For cattle feed or gasification processes, the solid deposit from the process may be used. This encourages the economic reduction of offset feedstock costs, which typically make up 55-80 percent of the final purchasing cost of alcohol[74,75]. The development of ethanol via microalgae involves an extra pretreatment step in which starch is extracted either by mechanical or enzymatic means from the cultured microalgae; the remainder of the procedure is exactly the same as previously mentioned. It is possible to divide the pretreatment process into physical, chemical, and biological approaches [76]. For the hydrolysis of algal biomass, acids and enzymes (at high or small concentrations) are widely used. The goal of using high concentrations of sulfuric acid is to break down biomass intra- and inter- $\mathrm{H}$ bonds. In order to release the fermentable sugars, there is then a drop in acid concentrations. The low concentrations acid method was specifically a two-stage device to ensure the discharge of structurally varying sugars such as hemicelluloses and cellulose. The inclusion of $2.5 \% \mathrm{MgCl}_{2}$ in $2 \% \mathrm{HCl}$ for biomass hydrolysis caused more than $83 \%$ of the total sugars containing mainly glucose, xylose, and arabinose to recover. This was a synergistic outcome since the effect of both of the constituents was greater than the entire amount of sugar discharged separately [77], proposed a combined technology focused on acid-catalyzed algal biomass pretreatment with low temperatures and low acidity to extract lipids and soluble sugars [78,79] simultaneously. Starch is consumed during enzymatic hydrolysis, and fermentable sugars are formed by using two enzymes: a-amylase and glucoamylase. Cellulase is a cellulosic substance and is commonly used in algal biomass hydrolysis. Microalgae species such as Chlorella vulgaris are a high source of starch ( 37 percent by weight), thus C. At up to 65 percent ethanol conversion efficiency, vulgaris biomass may be a good ethanol supply. Using marine green microalgae (Chlorococcum littorale) under dark and anaerobic conditions, it was possible to produce 450 mol g ${ }^{-1}$ dry weight of ethanol at $30{ }^{\circ} \mathrm{C}$. Tab. 6 summarizes the studies performed to generate bioethanol Figure 8.

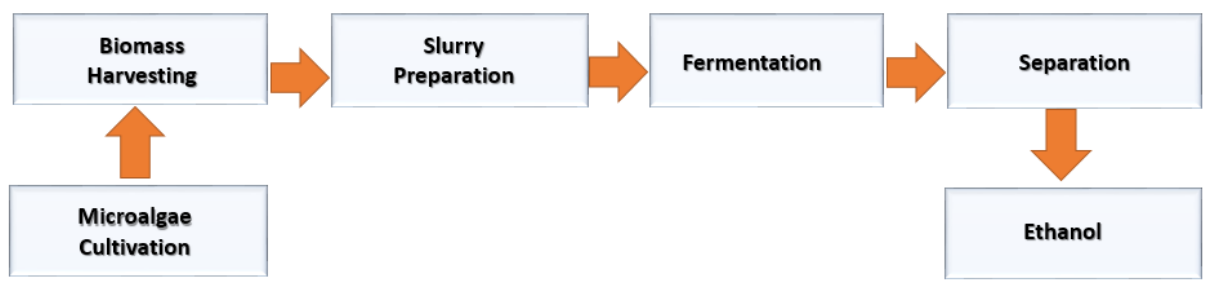

Figure 8. Schematic of the overall fermentation process for ethanol production.

Table 6. Production of Bioethanol by Hydrolysis and fermentation

\begin{tabular}{c|c|c|c|c|c} 
Microorganism & $\mathbf{X}\left[\mathbf{g L}^{-\mathbf{1}}\right]$ & $\begin{array}{c}\text { Productivity [g } \\
\text { ethanol L } \mathbf{L}^{-1} \mathbf{- 1}\end{array}$ & Type of hydrolysis & $\begin{array}{c}\text { Yield of } \\
\text { fermentation [\%] }\end{array}$ & Ref. \\
\hline Chlorella sp. KR-1 & 50 & $12-14$ & Enzymatic (pectinase) & 80 & {$[80]$} \\
\hline Chlorella vulgaris & 10 & 0.58 & Enzymatic (pectinase) & 89 & {$[81]$} \\
\hline Dunaliella tertiolecta & 50 & $8-9$ & $\begin{array}{c}\text { Chemo-enzymatic } \\
\text { (amyloglucosidase and } \\
\text { HCl) }\end{array}$ & 82 & {$[82]$} \\
\hline Synechococcus & 100 & 30 & Enzymatic (glucanases) & 86 & {$[72]$}
\end{tabular}

\subsection{Production of butanol.}

Butanol is a colorless liquid that, at high concentrations, causes a narcotic effect. Due to its high solubility in organic solvents and low miscibility in water, it is used as a solvent in biopharmaceutical, chemical, and cosmetic applications. Its physical properties closely resemble those of gasoline, making it a possible partial or full additive to fuel transport. Butanol 
can also be used as a gasoline-driven engine substitute fuel with minimal to no modifications; it can also be combined with gasoline in a much higher composition than ethanol because butanol has an energy content close to that of gasoline. In comparison to ethanol, it can be added to gasoline at the refinery and circulated via the current gasoline pipeline, as butanol is less corrosive and does not absorb water [83]. It is possible to synthesize butanol, a four-carbon primary alcohol, both chemically and biochemically; butanol's chemical synthesis is carried out mainly through three methods: Oxo synthesis, Reppe synthesis, and hydrogenation crotonaldehyde. However, the topic of this chapter is restricted to the biochemical conversion of Butanol biomass Butanol is a fermentation result of anaerobic bacteria in the metabolic cycle. Acetobutyliticum clostridium, Butyricum clostridium, etc. During World War I, the industrial development of butanol dates back to 1914 as a by-product of the production of acetone (used in war ammunition) by fermentation. While there was no immediate application of butanol during that period, it was used in the USA later in the 1920s to replace amyl acetate, a substance derived from amyl alcohol, a lacquer solvent in the automotive industry [84]. By the 1950 s, $66 \%$ of the butanol used in the world was biochemically made. However, due to higher biomass costs and low crude oil prices, butanol was replaced as a transportation fuel by crude oil. Substrates used to produce butanol may come from both starch and cellulose, such as molasses, corn fiber, wheat straw, etc. However, the controversy over the use of food substrates for fuel production regulates the use of starch-based substrates. Butanol can also be included in Figure 9, which illustrates the flow of processes for ethanol. However, biomass fermentation is carried out by bacteria containing butanol. Via the glucose-pyruvatebutyraldehyde pathway, butanol formation takes place. Butanol fermentation is a biphasic transformation that takes place during the exponential growth period and solventogenic phase, consisting of an acidogenic phase. Acid-forming pathways are triggered during the acidogenic process, and the key products produced include acetate, butyrate, hydrogen, and carbon dioxide. Solventogenic process products that arise during the exponential growth phase are acetone, butanol, and ethanol/propanol. The solventogenic phase is a reaction to the increased solventogenic phase production of acid during the acidogenic process, which would lead to a decrease in extracellular $\mathrm{pH}$ if not initiated, and finally to cell death due to the increasing gradient of protons between inner and outer cell environments. $\mathrm{pH}$ regulation, therefore, has a very important impact on the production of butanol, and for the solventogenic process, it needs to be in the acid range. Another major concern that causes cell death is solvent toxicity due to the weakening of the cell wall in the presence of acetone, ethanol, and butanol (the most toxic compound), leading to low concentrations and productivity of the substance [85]. By continuous elimination of the solvents by different unit operations, solvent toxicity can be overcome. Traditionally, butanol is separated by distillation, which is a cost-intensive process due to its high boiling point. Adsorption, gas stripping, liquid-liquid extraction, prescription, pervaporation, and reverse osmosis are alternative methods for butanol separation. Each of these processes has certain drawbacks, among which, despite low selectivity, gas stripping is easy and effective as it can be used for butanol removal in a continuous operation. The use of a solvent that is non-inhibitory to the microbes is needed for liquid-liquid extraction. Butanol is selectively diffused through the membrane during pervaporation and evaporated without removing the medium components required for microbial growth. Nevertheless, it is restricted by the fouling of membranes by the particles found in the broth of fermentation. 


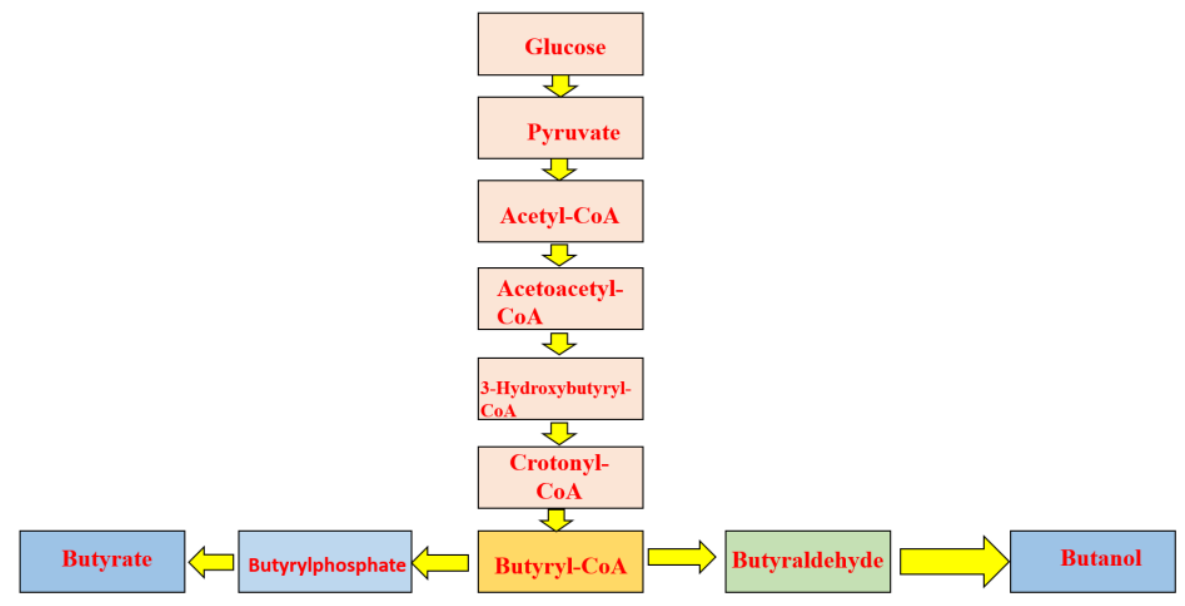

Figure 9. Butanol fermentation pathway of Clostridium acetobutylicum.

\subsection{Production of biohydrogen.}

Hydrogen $\left(\mathrm{H}_{2}\right)$ is an energy resource with very high latent heat that is environmentally friendly. It is important to remember that it is feasible for both photo-fermentation and darkfermentation to produce anaerobic hydrogen. Photobiological, microalgae can produce $\mathrm{H}_{2}$ because they have the metabolic and enzymatic features to do so. Usually, under anaerobic conditions, Eukaryotic-type microalgae can generate $\mathrm{H}^{+}$and oxygen during $\mathrm{CO}_{2}$ fixation in reaction conditions. By using these hydrogen ions, the $\mathrm{H}_{2}$ gas molecules are then produced in the presence of a hydrogenase enzyme [84]. The potential routes for the development of hydrogen using glucose as a model substrate are led by acetate (Eq. 3) or butyrate (Eq. 4) production:

$$
\begin{array}{lr}
\text { Glucose }+2 \mathrm{H}_{2} \mathrm{O} \longrightarrow 2 \text { Acetate }+2 \mathrm{CO}_{2}+4 \mathrm{H}_{2} & \Delta \mathrm{G}=-184 \mathrm{KJ} \\
\text { Glucose } \longrightarrow \text { Butyrate }+2 \mathrm{CO}_{2}+4 \mathrm{H}_{2} & \Delta \mathrm{G}=-257 \mathrm{KJ}
\end{array}
$$

Fermentation of acetate is well known to be energetically more desirable than fermentation of butyrate. And the efficiency of $\mathrm{H}_{2}$ in the first approach is potentially superior compared to the second approach. Melis and Happe recorded a two-stage photosynthesis process based on green algae in which a maximum yield of $200 \mathrm{~kg}$ of $\mathrm{H}_{2} \mathrm{ha}^{-1} \mathrm{~d}^{-1}$ is obtained. Hydrogen will pass dynamically between the product side and the reactant side, depending on the protons interacting with hydrogen, as the photosynthetic mechanism is reversible. The oxygen released during photosynthesis is very harmful to the $\mathrm{H}_{2}$-producing hydrogenase and should, as such, be subject to anaerobic conditions in the biomass culture. In addition, the byproducts (acetate and butyrate) can cause the product to inhibit the activities of microalgae during hydrogen fermentation. Particular care should therefore be taken to decrease product inhibition during biohydrogen production.

\subsection{Production of bioethanol from Sorghum.}

Via three key conversion processes, sorghum biomass is transformed into many major biofuels such as bioethanol, biodiesel, biohydrogen, biogas, bio-oil, biochar, and syngas: chemical, thermochemical, and biological Figure 10. Chemical conversion is consistent with the transesterification of biodiesel from sorghum oil. Direct combustion, gasification, 
pyrolysis, and liquefaction are used in thermochemical conversion. Since direct combustion, under air conditions, uses sorghum biomass as a solid fuel to generate heat, it is not considered here at all. Incomplete oxidation of sorghum biomass, which creates syngas consisting of $\mathrm{CO}$, $\mathrm{CO}_{2}$, and hydrogen, is gasification [84]. Pyrolysis is the high-temperature decomposition of sorghum biomass that creates biochar, bio-oil, and syngas in the partial or complete absence of oxygen. Specifically, in the absence of oxygen at high temperatures, torrefaction transforms biomass into biochar. Hydrothermal liquefaction (HTL) transforms sorghum biomass into biooil at high temperatures and pressures [23,24,85]. Two microbiological processes are involved in biological conversion: Anaerobic digestion and alcoholic fermentation. Alcoholic fermentation is used using ethanol-producing microorganisms to generate bioethanol from sorghum sugars, starch, and lignocellulosic materials. Anaerobic digestion using a collection of microorganisms creates biohydrogen and biogas from properly pretreated sorghum biomass $[25-27,86]$.

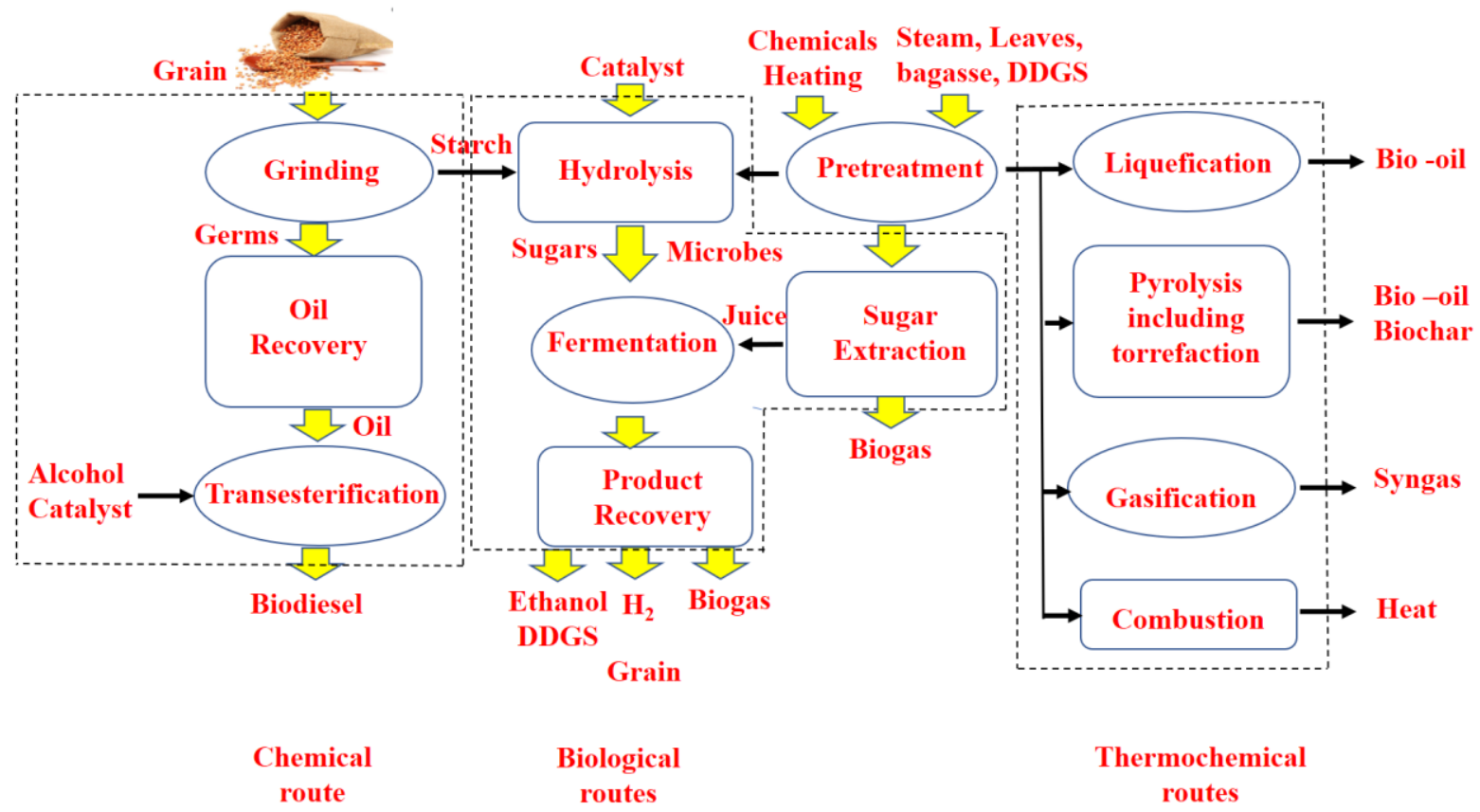

Figure 10. Routes of sorghum conversion into biofuels.

\section{Conclusions}

Because conventional fossil fuels like coal and petroleum are nonrenewable, they cannot supply the world's ever-increasing energy demands. Furthermore, increased global warming as a result of unconstrained $\mathrm{CO}_{2}$ emissions has become a major environmental concern. Bioenergy is a good alternative to address this issue because it is renewable, environmentally benign, and has the potential to create jobs. The primary feedstock (agricultural, food waste, municipal solid waste, algal biomass, waste cooking) is converted using various relevant conversion procedures and can be transformed to renewable and nontoxic biofuel (ethanol, biodiesel, and biobutanol). The conversion techniques could be thermochemical (including pyrolysis, gasification, and direct liquefaction) or biochemical and biological. The present review is an attempt to discuss the latest advances in the field of biofuels. Nanotechnology has proved to be an emerging breakthrough in biofuel industries that can help to reduce the cost due to increased reusability of immobilized enzymes, and biofuel yields can be enhanced multifold. Blending nanomaterials with biofuel would certainly lower the emission of toxic gases. Moreover, the less energy exhaustive distillation routes viz., feed 
splitting, ohmic distillation, membrane technology, and pervaporation processes can be better alternatives to economically and ecologically viable biofuel production. The high purity bioethanol can be achieved through these processes to sustain and compete in real-world applications.

Reports covering bioengineering of microorganisms and crops have also been intensively analyzed as the strain improvement techniques have an immense significance for improving the yields. This review presents an overview of the present-day scenario on recent developments and sustainability aspects in bioenergy and biofuels. The majority of studies considered can be performed at the bench or pilot scales. However, more research efforts need to be focused on practical aspects of technology development and newer methods of producing energy sources to support benign environmental management. Extensive research efforts and well-organized and reproducible rational investigations are needed to foster the knowledge transfer to practitioners for developing close interactions between academia, policymakers, and practitioners, offering clean environmental management for the benefit of society.

\section{Funding}

This research received no external funding.

\section{Acknowledgments}

The authors declare no acknwoledgments.

\section{Conflicts of Interest}

The authors declare no conflict of interest.

\section{References}

1. Saha, B.C.; Qureshi, N.; Kennedy, G.J.; Cotta, M.A. Biological pretreatment of corn stover with white-rot fungus for improved enzymatic hydrolysis. International Biodeterioration \& Biodegradation 2016, 109, 2935, https://doi.org/10.1016/j.ibiod.2015.12.020.

2. Philippini, R.R.; Martiniano, S.E.; Chandel, A.K.; de Carvalho, W.; da Silva, S.S. Pretreatment of sugarcane bagasse from cane hybrids: effects on chemical composition and $2 \mathrm{G}$ sugars recovery. Waste and Biomass Valorization 2019, 10, 1561-1570, https://doi.org/10.1007/s12649-017-0162-0.

3. Sindhu, R.; Binod, P.; Pandey, A. Biological pretreatment of lignocellulosic biomass-An overview. Bioresource technology 2016, 199, 76-82, https://doi.org/10.1016/j.biortech.2015.08.030.

4. Isroi, I.; Millati, R.; Niklasson, C.; Cayanto, C.; Taherzadeh, M.J.; Lundquist, K. Biological treatment of Lignocelluloses with white-rot funghi and its applications. BioResources 2011, 6, 5224-5259.

5. Arora, R.; Sharma, N.K.; Kumar, S. Valorization of by-products following the biorefinery concept: commercial aspects of by-products of lignocellulosic biomass. In Advances in Sugarcane Biorefinery; Elsevier: 2018; 163-178, https://doi.org/10.1016/B978-0-12-804534-3.00008-2.

6. Singh, J.; Gu, S. Commercialization potential of microalgae for biofuels production. Renewable and sustainable energy reviews 2010, 14, 2596-2610, https://doi.org/10.1016/j.rser.2010.06.014.

7. Ejaz, A.; Pant, K.K. Lignin conversion: a key to the concept of lignocellulosic biomass-based integrated biorefinery. In Waste biorefinery; Elsevier: 2018; 409-444, https://doi.org/10.1016/B978-0-444-639929.00014-8.

8. Zabed, H.; Sultana, S.; Sahu, J.N.; Qi, X. An overview on the application of ligninolytic microorganisms and enzymes for pretreatment of lignocellulosic biomass. Recent advancements in biofuels and bioenergy utilization 2018, 53-72, https://doi.org/10.1007/978-981-13-1307-3_3.

9. Zhao, X.; Luo, K.; Zhang, Y.; Zheng, Z.; Cai, Y.; Wen, B.; Cui, Z.; Wang, X. Improving the methane yield of maize straw: focus on the effects of pretreatment with fungi and their secreted enzymes combined with 


sodium hydroxide. $\quad$ Bioresource technology 2013,
https://doi.org/10.1016/j.biortech.2017.09.160.

10. Saratale, R.G.; Kumar, G.; Banu, R.; Xia, A.; Periyasamy, S.; Saratale, G.D. A critical review on anaerobic digestion of microalgae and macroalgae and co-digestion of biomass for enhanced methane generation. Bioresource technology 2018, 262, 319-332, https://doi.org/10.1016/j.biortech.2018.03.030.

11. Hassan, N.; El-Sonbati, A.; El-Desouky, M. Synthesis, characterization, molecular docking and DNA binding studies of Cu (II), Ni (II), Zn (II) and Mn (II) complexes. Journal of Molecular Liquids 2017, 242, 293-307, https://doi.org/10.1016/j.molliq.2017.07.019.

12. El-Desouky, M.G.; Shahat, A.; El-Bindary, A.A.; El-Bindary, M.A. Description, Kinetic and Equilibrium Studies of the Adsorption of Carbon Dioxide in Mesoporous Iron Oxide Nanospheres. Biointerface Resarch in Applied Chemistry 2021, 12, 1022-1038, https://doi.org/10.33263/BRIAC121.10221038.

13. Vasco-Correa, J.; Ge, X.; Li, Y. Fungal pretreatment of non-sterile miscanthus for enhanced enzymatic hydrolysis. Bioresource technology 2016, 203, 118-123, https://doi.org/10.1016/j.biortech.2015.12.018.

14. Harun, R.; Danquah, M.K. Enzymatic hydrolysis of microalgal biomass for bioethanol production. Chemical Engineering Journal 2011, 168, 1079-1084, https://doi.org/10.1016/j.cej.2011.01.088.

15. Passos, F.; Uggetti, E.; Carrère, H.; Ferrer, I. Pretreatment of microalgae to improve biogas production: a review. Bioresource technology 2014, 172, 403-412, https://doi.org/10.1016/j.biortech.2014.08.114.

16. Barua, V.B.; Goud, V.V.; Kalamdhad, A.S. Microbial pretreatment of water hyacinth for enhanced hydrolysis followed by biogas production. Renewable Energy 2018, 126, 21-29, https://doi.org/10.1016/j.renene.2018.03.028.

17. Nigam, P.S.; Singh, A. Production of liquid biofuels from renewable resources. Progress in energy and combustion science 2011, 37, 52-68, https://doi.org/10.1016/j.pecs.2010.01.003.

18. Gumienna, M.; Szambelan, K.; Jeleń, H.; Czarnecki, Z. Evaluation of ethanol fermentation parameters for bioethanol production from sugar beet pulp and juice. Journal of the Institute of Brewing 2014, 120, 543-549, https://doi.org/10.1002/jib.181.

19. Astolfi, A.L.; Rempel, A.; Cavanhi, V.A.F.; Alves, M.; Deamici, K.M.; Colla, L.M.; Costa, J.A.V. Simultaneous saccharification and fermentation of Spirulina sp. and corn starch for the production of bioethanol and obtaining biopeptides with high antioxidant activity. Bioresource technology 2020, 301, 122698, https://doi.org/10.1016/j.biortech.2019.122698.

20. Jutakridsada, P.; Saengprachatanarug, K.; Kasemsiri, P.; Hiziroglu, S.; Kamwilaisak, K.; Chindaprasirt, P. Bioconversion of Saccharum officinarum leaves for ethanol production using separate hydrolysis and fermentation processes. Waste and Biomass Valorization 2019, 10, 817-825, https://doi.org/10.1007/s12649017-0104-X.

21. Kumar, S.; Banerjee, R. Enzymatic delignification and saccharification of Bambusa bambos for biobutanol $\begin{array}{llllll}\text { production. Industrial Crops and Products } & \text { 2018, }\end{array}$ https://doi.org/10.1016/j.indcrop.2018.09.015.

22. Jiang, W.; Brueggeman, A.J.; Horken, K.M.; Plucinak, T.M.; Weeks, D.P. Successful transient expression of Cas9 and single guide RNA genes in Chlamydomonas reinhardtii. Eukaryotic cell 2014, 13, 1465-1469, https://doi.org/10.1128/EC.00213-14.

23. Sipra, A.T.; Gao, N.; Sarwar, H. Municipal solid waste (MSW) pyrolysis for bio-fuel production: A review of effects of MSW components and catalysts. Fuel processing technology 2018, 175, 131-147, https://doi.org/10.1016/j.fuproc.2018.02.012.

24. Azizi, K.; Moraveji, M.K.; Najafabadi, H.A. A review on bio-fuel production from microalgal biomass by using pyrolysis method. Renewable and Sustainable Energy Reviews 2018, 82, 3046-3059, https://doi.org/10.1016/j.rser.2017.10.033.

25. Huang, J.; Xia, T.; Li, G.; Li, X.; Li, Y.; Wang, Y.; Wang, Y.; Chen, Y.; Xie, G.; Bai, F.-W. Overproduction of native endo- $\beta-1$, 4-glucanases leads to largely enhanced biomass saccharification and bioethanol production by specific modification of cellulose features in transgenic rice. Biotechnology for Biofuels 2019, 12, 1-15, https://doi.org/10.1186/s13068-018-1351-1.

26. Kumar, R.; Strezov, V.; Weldekidan, H.; He, J.; Singh, S.; Kan, T.; Dastjerdi, B. Lignocellulose biomass pyrolysis for bio-oil production: A review of biomass pretreatment methods for production of drop-in fuels. Renewable and Sustainable Energy Reviews 2020, 123, 109763, https://doi.org/10.1016/j.rser.2020.109763.

27. Neves, R.C.; Klein, B.C.; da Silva, R.J.; Rezende, M.C.A.F.; Funke, A.; Olivarez-Gómez, E.; Bonomi, A.; Maciel-Filho, R. A vision on biomass-to-liquids (BTL) thermochemical routes in integrated sugarcane 
biorefineries for biojet fuel production. Renewable and Sustainable Energy Reviews 2020, 119, 109607, https://doi.org/10.1016/j.rser.2019.109607.

28. Sanusi, I.A.; Faloye, F.D.; Kana, E.G. Impact of various metallic oxide nanoparticles on ethanol production by Saccharomyces cerevisiae BY4743: screening, kinetic study and validation on potato waste. Catalysis Letters 2019, 149, 2015-2031, https://doi.org/10.1007/s10562-019-02796-6.

29. Koti, S.; Govumoni, S.P.; Gentela, J.; Rao, L.V. Enhanced bioethanol production from wheat straw hemicellulose by mutant strains of pentose fermenting organisms Pichia stipitis and Candida shehatae. SpringerPlus 2016, 5, 1-9, https://doi.org/10.1186/s40064-016-3222-1.

30. Gao, X.; Gao, Q.; Bao, J. Improving cellulosic ethanol fermentability of Zymomonas mobilis by overexpression of sodium ion tolerance gene ZMO0119. Journal of biotechnology 2018, 282, 32-37, https://doi.org/10.1016/j.jbiotec.2018.05.013.

31. Binhayeeding, N.; Yunu, T.; Pichid, N.; Klomklao, S.; Sangkharak, K. Immobilisation of Candida rugosa lipase on polyhydroxybutyrate via a combination of adsorption and cross-linking agents to enhance acylglycerol production. $\quad$ Process Biochemistry $2020, \quad 95, \quad$ 174-185, https://doi.org/10.1016/j.procbio.2020.02.007.

32. Tavan, Y.; Shahhosseini, S. Feed-Splitting as Energy-Saving Technique in the Heterogeneous Distillation of Ethanol-Water Azeotropes. Energy Technology 2016, 4, 424-428, https://doi.org/10.1002/ente.201500287.

33. Baeyens, J.; Kang, Q.; Appels, L.; Dewil, R.; Lv, Y.; Tan, T. Challenges and opportunities in improving the production of bio-ethanol. Progress in Energy and Combustion Science 2015, 47, 60-88, https://doi.org/10.1016/j.pecs.2014.10.003.

34. Gavahian, M.; Farahnaky, A.; Sastry, S. Multiple effect concentration of ethanol by ohmic-assisted hydrodistillation. Food and Bioproducts Processing 2016, 100, 85-91, https://doi.org/10.1016/j.fbp.2016.06.002.

35. Kumar, V.; Nanda, M.; Joshi, H.; Singh, A.; Sharma, S.; Verma, M. Production of biodiesel and bioethanol using algal biomass harvested from fresh water river. Renewable Energy 2018, 116, 606-612, https://doi.org/10.1016/j.renene.2017.10.016.

36. Sharma, S.; Nandal, P.; Arora, A. Ethanol production from $\mathrm{NaOH}$ pretreated rice straw: a cost effective option to manage rice crop residue. Waste and Biomass Valorization 2019, 10, 3427-3434, https://doi.org/10.1007/s12649-018-0360-4.

37. Zabed, H.M.; Akter, S.; Yun, J.; Zhang, G.; Awad, F.N.; Qi, X.; Sahu, J. Recent advances in biological pretreatment of microalgae and lignocellulosic biomass for biofuel production. Renewable and Sustainable Energy Reviews 2019, 105, 105-128, https://doi.org/10.1016/j.rser.2019.01.048.

38. Silva, G.G.D.; Guilbert, S.; Rouau, X. Successive centrifugal grinding and sieving of wheat straw. Powder technology 2011, 208, 266-270, https://doi.org/10.1016/j.powtec.2010.08.015.

39. Martinez-Hernandez, E.; Tibessart, A.; Campbell, G.M. Conceptual design of integrated production of arabinoxylan products using bioethanol pinch analysis. Food and Bioproducts Processing 2018, 112, 1-8, https://doi.org/10.1016/j.fbp.2018.08.005.

40. Zhao, B.-H.; Chen, J.; Yu, H.-Q.; Hu, Z.-H.; Yue, Z.-B.; Li, J. Optimization of microwave pretreatment of lignocellulosic waste for enhancing methane production: Hyacinth as an example. Frontiers of Environmental Science \& Engineering 2017, 11, 1-9, https://doi.org/10.1007/s11783-017-0965-z.

41. Morone, A.; Chakrabarti, T.; Pandey, R. Assessment of alkaline peroxide-assisted wet air oxidation pretreatment for rice straw and its effect on enzymatic hydrolysis. Cellulose 2017, 24, 4885-4898, https://doi.org/10.1007/s10570-017-1451-2.

42. Hassan, N.; Shahat, A.; El-Didamony, A.; El-Desouky, M.; El-Bindary, A. Mesoporous iron oxide nano spheres for capturing organic dyes from water sources. Journal of Molecular Structure 2020, 1217, 128361, https://doi.org/10.1016/j.molstruc.2020.128361.

43. Alvira, P.; Tomás-Pejó, E.; Ballesteros, M.; Negro, M.J. Pretreatment technologies for an efficient bioethanol production process based on enzymatic hydrolysis: a review. Bioresource technology 2010, 101, 4851-4861, https://doi.org/10.1016/j.biortech.2009.11.093.

44. Mosier, N.; Wyman, C.; Dale, B.; Elander, R.; Lee, Y.; Holtzapple, M.; Ladisch, M. Features of promising technologies for pretreatment of lignocellulosic biomass. Bioresource technology 2005, 96, 673-686, https://doi.org/10.1016/j.biortech.2004.06.025.

45. Taherzadeh, M.J.; Karimi, K. Pretreatment of lignocellulosic wastes to improve ethanol and biogas production: a review. International journal of molecular sciences 2008, 9, 1621-1651, https://doi.org/10.3390/ijms9091621. 
46. Brodeur, G.; Yau, E.; Badal, K.; Collier, J.; Ramachandran, K.; Ramakrishnan, S. Chemical and physicochemical pretreatment of lignocellulosic biomass: a review. Enzyme research 2011, 2011, https://doi.org/10.4061/2011/787532.

47. Ashraf, A.; El-Desouky, M.G.; El-Afify, M.A. Thermal and Spectroscopic Studies of Some Prepared Metal Complexes and Investigation of their Potential Anticancer and Antiviral Drug Activity against SARS-CoV2 by Molecular Docking Simulation. Biointerface Resarch in Applied Chemistry 2021, 12, 1053-1075, https://doi.org/10.33263/BRIAC121.10531075.

48. Kuila, A.; Mukhopadhyay, M.; Tuli, D.; Banerjee, R. Production of ethanol from lignocellulosics: an enzymatic venture. EXCLI journal 2011, 10, 85.

49. Duff, S.J.; Murray, W.D. Bioconversion of forest products industry waste cellulosics to fuel ethanol: a review. Bioresource technology 1996, 55, 1-33, https://doi.org/10.1016/0960-8524(95)00122-0.

50. Divya, D.; Gopinath, L.; Christy, P.M. A review on current aspects and diverse prospects for enhancing biogas production in sustainable means. Renewable and sustainable energy reviews 2015, 42, 690-699, https://doi.org/10.1016/j.rser.2014.10.055.

51. Zhang, Q.; Hu, J.; Lee, D.-J. Biogas from anaerobic digestion processes: Research updates. Renewable Energy 2016, 98, 108-119, https://doi.org/10.1016/j.renene.2016.02.029.

52. Mohamed, G.; Hassan, N.; Shahat, A.; El-Didamony, A.; Ashraf, A. Synthesis and characterization of porous magnetite nanosphere iron oxide as a novel adsorbent of anionic dyes removal from aqueous solution.

Biointerface Resarch in Applied Chemistry 2021, 11, 13377-13401, https://doi.org/10.33263/BRIAC115.1337713401.

53. Hashemi, S.S.; Karimi, K.; Karimi, A.M. Ethanolic ammonia pretreatment for efficient biogas production from sugarcane bagasse. Fuel 2019, 248, 196-204, https://doi.org/10.1016/j.fuel.2019.03.080.

54. Rajput, A.A.; Visvanathan, C. Effect of thermal pretreatment on chemical composition, physical structure and biogas production kinetics of wheat straw. Journal of environmental management 2018, 221, 45-52, https://doi.org/10.1016/j.jenvman.2018.05.011.

55. Lü, F.; Ji, J.; Shao, L.; He, P. Bacterial bioaugmentation for improving methane and hydrogen production from microalgae. Biotechnology for biofuels 2013, 6, 1-11, https://doi.org/10.1186/1754-6834-6-92.

56. Lakaniemi, A.-M.; Hulatt, C.J.; Thomas, D.N.; Tuovinen, O.H.; Puhakka, J.A. Biogenic hydrogen and methane production from Chlorella vulgaris and Dunaliella tertiolecta biomass. Biotechnology for biofuels 2011, 4, 1-12, https://doi.org/10.1186/1754-6834-4-34.

57. Mussgnug, J.H.; Klassen, V.; Schlüter, A.; Kruse, O. Microalgae as substrates for fermentative biogas production in a combined biorefinery concept. Journal of biotechnology 2010, 150, 51-56, https://doi.org/10.1016/j.jbiotec.2010.07.030.

58. Vergara-Fernández, A.; Vargas, G.; Alarcón, N.; Velasco, A. Evaluation of marine algae as a source of biogas in a two-stage anaerobic reactor system. Biomass and Bioenergy 2008, 32, 338-344, https://doi.org/10.1016/j.biombioe.2007.10.005.

59. Chen, P.H. Factors influencing methane fermentation of micro-algae; California Univ., Berkeley (USA): 1987.

60. Lindorfer, H.; Corcoba, A.; Vasilieva, V.; Braun, R.; Kirchmayr, R. Doubling the organic loading rate in the co-digestion of energy crops and manure-a full scale case study. Bioresource technology 2008, 99, 11481156, https://doi.org/10.1016/j.biortech.2007.02.033.

61. El-Desouky, M.G.; Abd El-Wahab, M.; El-Bindary, A.A. Interpretations and DFT Calculations for Polypropylene/Cupper Oxide Nanosphere. Biointerface Resarch in Applied Chemistry 2021, 12, 1134-1147, https://doi.org/10.33263/BRIAC121.11341147.

62. Li, Y.; Tang, W.; Chen, Y.; Liu, J.; Chia-fon, F.L. Potential of acetone-butanol-ethanol (ABE) as a biofuel. Fuel 2019, 242, 673-686, https://doi.org/10.1016/j.fuel.2019.01.063.

63. Ibrahim, M.F.; Kim, S.W.; Abd-Aziz, S. Advanced bioprocessing strategies for biobutanol production from biomass. Renewable and Sustainable Energy Reviews 2018, 91, 1192-1204, https://doi.org/10.1016/j.rser.2018.04.060.

64. Zhang, J.; Jia, B. Enhanced butanol production using Clostridium beijerinckii SE-2 from the waste of corn processing. Biomass and Bioenergy 2018, 115, 260-266, https://doi.org/10.1016/j.biombioe.2018.05.012.

65. Alfonsín, V.; Maceiras, R.; Gutiérrez, C. Bioethanol production from industrial algae waste. Waste Management 2019, 87, 791-797, https://doi.org/10.1016/j.wasman.2019.03.019. 
66. Wyman, C.E.; Dale, B.E.; Elander, R.T.; Holtzapple, M.; Ladisch, M.R.; Lee, Y. Coordinated development of leading biomass pretreatment technologies. Bioresource technology 2005, 96, 1959-1966, https://doi.org/10.1016/j.biortech.2005.01.010.

67. Voloshin, R.A.; Rodionova, M.V.; Zharmukhamedov, S.K.; Veziroglu, T.; Allakhverdiev, S.I. Review: Biofuel Production from Plant and Algal Biomass. Alternative Energy and Ecology (ISJAEE) 2019, 12-31.

68. Klinthong, W.; Yang, Y.-H.; Huang, C.-H.; Tan, C.-S. A review: microalgae and their applications in CO2 capture and renewable energy. Aerosol and Air Quality Research 2015, 15, 712-742, https://doi.org/10.4209/aaqr.2014.11.0299.

69. Zhou, N.; Zhang, Y.; Wu, X.; Gong, X.; Wang, Q. Hydrolysis of Chlorella biomass for fermentable sugars in the presence of $\mathrm{HCl}$ and $\mathrm{MgCl} 2$. Bioresource technology 2011, 102, 10158-10161, https://doi.org/10.1016/j.biortech.2011.08.051.

70. Hassan, N.; Shahat, A.; El-Didamony, A.; El-Desouky, M.; El-Bindary, A. Equilibrium, Kinetic and Thermodynamic studies of adsorption of cationic dyes from aqueous solution using ZIF-8. Moroccan Journal of Chemistry 2020, 8, 2627-2637.

71. Laurens, L.; Nagle, N.; Davis, R.; Sweeney, N.; Van Wychen, S.; Lowell, A.; Pienkos, P. Acid-catalyzed algal biomass pretreatment for integrated lipid and carbohydrate-based biofuels production. Green Chemistry 2015, 17, 1145-1158, https://doi.org/10.1039/C4GC01612B.

72. Hassan, N.; Shahat, A.; El-Didamony, A.; El-Desouky, M.; El-Bindary, A. Synthesis and characterization of $\mathrm{ZnO}$ nanoparticles via zeolitic imidazolate framework-8 and its application for removal of dyes. Journal of molecular structure 2020, 1210, 128029, https://doi.org/10.1016/j.molstruc.2020.128029.

73. Ramachandriya, K.D.; Kundiyana, D.K.; Sharma, A.M.; Kumar, A.; Atiyeh, H.K.; Huhnke, R.L.; Wilkins, M.R. Critical factors affecting the integration of biomass gasification and syngas fermentation technology. 2016, https://doi.org/10.3934/bioeng.2016.2.188.

74. Hirano, A.; Hon-Nami, K.; Kunito, S.; Hada, M.; Ogushi, Y. Temperature effect on continuous gasification of microalgal biomass: theoretical yield of methanol production and its energy balance. Catalysis Today 1998 , 45, 399-404, https://doi.org/10.1016/S0920-5861(98)00275-2.

75. Ueno, Y.; Kurano, N.; Miyachi, S. Ethanol production by dark fermentation in the marine green alga, Chlorococcum littorale. Journal of fermentation and bioengineering 1998, 86, 38-43, https://doi.org/10.1016/S0922-338X(98)80031-7.

76. Lee, D.-W.; Park, Y.-M.; Lee, K.-Y. Heterogeneous base catalysts for transesterification in biodiesel synthesis. Catalysis surveys from Asia 2009, 13, 63-77.

77. Kim, K.H.; Choi, I.S.; Kim, H.M.; Wi, S.G.; Bae, H.-J. Bioethanol production from the nutrient stressinduced microalga Chlorella vulgaris by enzymatic hydrolysis and immobilized yeast fermentation. Bioresource Technology 2014, 153, 47-54, https://doi.org/10.1016/j.biortech.2013.11.059.

78. Lee, O.K.; Kim, A.L.; Seong, D.H.; Lee, C.G.; Jung, Y.T.; Lee, J.W.; Lee, E.Y. Chemo-enzymatic saccharification and bioethanol fermentation of lipid-extracted residual biomass of the microalga, Dunaliella tertiolecta. Bioresource technology 2013, 132, 197-201, https://doi.org/10.1016/j.biortech.2013.01.007.

79. Möllers, K.B.; Cannella, D.; Jørgensen, H.; Frigaard, N.-U. Cyanobacterial biomass as carbohydrate and nutrient feedstock for bioethanol production by yeast fermentation. Biotechnology for biofuels 2014, 7, 1-11, https://doi.org/10.1186/1754-6834-7-64.

80. Lee, S.Y.; Park, J.H.; Jang, S.H.; Nielsen, L.K.; Kim, J.; Jung, K.S. Fermentative butanol production by Clostridia. Biotechnology and bioengineering 2008, 101, 209-228, https://doi.org/10.1002/bit.22003.

81. Dürre, P. Fermentative butanol production: bulk chemical and biofuel. Annals of the New York Academy of Sciences 2008, 1125, 353-362, https://doi.org/10.1196/annals.1419.009.

82. Qureshi, N.; Meagher, M.; Hutkins, R. Recovery of butanol from model solutions and fermentation broth using a silicalite/silicone membrane. Journal of Membrane Science 1999, 158, 115-125, https://doi.org/10.1016/S0376-7388(99)00010-1.

83. Carrillo, M.; Staggenborg, S.; Pineda, J. Washing sorghum biomass with water to improve its quality for combustion. Fuel 2014, 116, 427-431, https://doi.org/10.1016/j.fuel.2013.08.028.

84. Yin, R.; Liu, R.; Mei, Y.; Fei, W.; Sun, X. Characterization of bio-oil and bio-char obtained from sweet sorghum bagasse fast pyrolysis with fractional condensers. Fuel 2013, 112, 96-104, https://doi.org/10.1016/j.fuel.2013.04.090.

85. Yue, Y.; Kastner, J.R.; Mani, S. Two-stage hydrothermal liquefaction of sweet sorghum biomass-Part II: Production of upgraded biocrude oil. Energy \& Fuels 2018, 32, 7620-7629, https://doi.org/10.1021/acs.energyfuels.8b00669. 
86. Živković, S.B.; Veljković, M.V.; Banković-Ilić, I.B.; Krstić, I.M.; Konstantinović, S.S.; Ilić, S.B.; Avramović, J.M.; Stamenković, O.S.; Veljković, V.B. Technological, technical, economic, environmental, social, human health risk, toxicological and policy considerations of biodiesel production and use. Renewable and Sustainable Energy Reviews 2017, 79, 222-247, https://doi.org/10.1016/j.rser.2017.05.048. 